\title{
Tingkat Keberlanjutan Pemanfaatan Ruang Publik Multifungsi di Permukiman Kumuh
}

\author{
The Level of Sustainability of Multifunction Public Spaces \\ in Slum Area
}

Violla Caesandra ${ }^{1}$, Hanny Wahidin Wiranegara ${ }^{1}$ dan Sugihartoyo ${ }^{2}$

Diterima: 8 November 2019

Disetujui: 2 Juli 2020

\begin{abstract}
Abstrak: Terbatasnya ruang tempat tinggal di permukiman kumuh menyebabkan penghuninya memanfaatkan ruang publik untuk menampung sebagian kegiatannya. Salah satu ruang publik yang dimanfaatkan adalah taman. Ruang publik yang dimanfaatkan untuk berbagai macam kegiatan oleh penghuni di permukiman kumuh disebut sebagai ruang publik multifungsi. Pemanfaatan ruang publik multifungsi bersama-sama dapat berpotensi menimbulkan konflik pemanfaatan ruang sehingga dapat mengganggu keberkelanjutan fungsinya. Tujuan penelitian ini adalah teridentifikasinya tingkat keberlanjutan pemanfaatan ruang publik multifungsi di permukiman kumuh. Penelitian ini bersifat kuantitatif dengan menggunakan metode survey-angket kepada penghuni permukiman kumuh pengguna taman. Unit analisis dalam penelitian ini adalah taman. Jumlah responden pengguna taman ditentukan dengan menggunakan rumus Lemeshow sebanyak 96. Berdasarkan hasil penelitian dapat disimpulkan bahwa tingkat keberlanjutan pemanfaatan pada masingmasing taman berbeda satu sama lain. Pemanfaatan taman yang memiliki tingkat keberlanjutan tinggi adalah taman Pendongkelan, tingkat keberlanjutan sedang taman Melati Indah, dan tingkat keberlanjutan rendah taman Anggrek. Terdapat empat aspek keberlanjutan yang diukur. Aspek keragaman dan harmoni merupakan aspek pembeda tingkat keberlanjutan pemanfaatan taman. Dua aspek lainnya (interaksi dan interdependensi) relatif sama di tiga taman. Untuk keberlanjutan pemanfaatan ruang publik multifungsi di permukiman kumuh perlu pengelolaan yang memperhatikan luas taman, ketersediaan fasilitas taman dan aksesibilitas taman.
\end{abstract}

Kata Kunci: Ruang publik multifungsi; keberkelanjutan pemanfaatan; permukiman kumuh

Abstract: Due to the limitation of slum dweller's residence, they use public spaces for their daily activities. One kind of them is a park. Public space used for various kinds of activities is called a multifunction public space. Utilization of multifunction public space can potentially lead to spatial use conflict which interferes with its functional sustainability. The aim of this research was to identify the level of sustainability of the utilization of a multifunction public space in the slum area. This research used a quantitative approach and a questionnaire survey method. Respondents were slum dwellers using the park. The total respondents were 96 by using the Lemeshow formula. The results showed that there were differences in the level of sustainability among the three parks. The highest level of sustainable utilization is Pendongkelan, the medium level is Melati Indah, and

\footnotetext{
${ }^{1}$ Program Studi Perencanaan Wilayah dan Kota, Fakultas Arsitektur Lanskap dan Teknologi Lingkungan, Universitas Trisakti, Jakarta

${ }^{2}$ Program Studi Perencanaan Wilayah dan Kota, Universitas Esa Unggul, Jakarta.
}

Korespondensi: hanny.w@trisakti.ac.id 
the lowest level is Taman Anggrek. There were four aspects of sustainability measured. Diversity and harmony were the two aspects of determining sustainability. For sustainability of spatial use of the multifunction public space in the slum area needs management to take care of the size of the park, its amenities, and its accessibility.

Keywords: multifunction public space; sustainability of spatial utilization; slum area

\section{PENDAHULUAN}

Kota yang ideal memenuhi beberapa syarat penting, salah satunya adalah permukiman layak huni bagi para warganya (Lynch, 1997 dalam Banteng, 2015). Salah satu tujuan pembangunan perumahan dan kawasan permukiman berdasarkan UU No.1 Tahun 2011 adalah mewujudkan kawasan permukiman yang berkelanjutan. Saat ini pembangunan kota diarahkan untuk mencapai tujuan ke-11 dalam Sustainable Development Goals (SDGs) 2016-2030, yaitu membangun kota dan permukiman yang berkelanjutan. Seiring dengan makin meningkatnya jumlah penduduk dan di sisi lain adanya keterbatasan dalam penyediaan rumah yang layak, maka yang terjadi adalah makin luasnya permukiman kumuh di perkotaan.

Di DKI Jakarta saat ini luas permukiman kumuh mencapai 1.024,52 Ha $(1,55 \%)$ dari total keseluruhan luasnya. Kelurahan Kapuk memiliki permukiman kumuh terluas sebesar 125,61 Нa (12,26\%) jika dibandingkan dengan 124 kelurahan kumuh lainnya (Evaluasi RW Kumuh DKI Jakarta Tahun 2013). Dengan ukuran ruang tempat tinggal yang tidak memadai kebutuhan keluarga, maka di permukiman kumuh cenderung timbul pemanfaatan ruang publik secara multifungsi yang dapat merangsang munculnya konflik pemanfaatan ruang yang mengganggu keberlanjutannya. Saat ini dijumpai pemanfaatan ruang terbuka yang tidak semestinya serta perawatan dan pengawasan kurang optimal sehingga menyebabkan turunnya fungsi ruang tersebut (Rizka, 2012). Oleh karena itu, diperlukan pengetahuan tentang tingkat keberlanjutan pemanfaatan ruang publik multifungsi di permukiman kumuh.

Penelitian ini diarahkan untuk menjawab pertanyaan seberapa besar tingkat keberlanjutan pemanfaatkan ruang publik multifungsi di permukiman kumuh?. Tujuan penelitian ini adalah teridentifikasinya tingkat keberlanjutan pemanfaatan ruang publik multifungsi di permukiman kumuh dengan taman dipilih sebagai kasusnya.

\section{Lokasi Penelitian}

Penelitian ini dilakukan di 3 (tiga) taman yang terdapat di RW 09 Kelurahan Kapuk, yaitu taman Pendongkelan, taman Melati Indah, dan taman Anggrek, seperti diperlihatkan pada Gambar 1. Masing-masing taman memiliki karakteristik fisik yang berbeda, seperti dalam penggunaan lahan di sekitar taman, aksesibilitas, ketersediaan fasilitas, dan luas taman. Karakteristik taman tersebut digunakan sebagai variabel dalam mengukur perbedaan tingkat keberlanjutan dan mengidentifikasi unsur-unsur yang mempengaruhi tingkat keberlanjutan pemanfaatan taman. Untuk mengukur tingkat keberlanjutan pemanfaatan taman digunakan aspek interaksi, interdependensi, keragaman, dan harmoni dalam pemanfaatan masing-masing taman yang dipilih sebagai kasus.

\section{Permukiman Kumuh di Perkotaan}

Berdasarkan Undang-undang No. 1 Tahun 2011 tentang Perumahan dan Kawasan Permukiman, permukiman kumuh merupakan permukiman yang tidak layak huni karena ketidakteraturan bangunan, tingkat kepadatan bangunan yang tinggi, dan kualitas bangunan serta sarana dan prasarana yang tidak memenuhi syarat. Dalam menentukan permukiman kumuh dapat digunakan aspek sosial-ekonomi dan fisik lingkungan. Aspek sosial-ekonomi meliputi kepadatan, cara membuang sampah, tingkat pendidikan, serta 
tingkat pendapatan. Aspek fisik lingkungan meliputi tata bangunan, konstruksi bangunan, ventilasi, pemanfaatan lahan, keadaan jalan, drainase, tempat buang air besar, pengangkutan sampah, dan penerangan jalan umum (Khomarudin, 1997 dalam Budiawan, 2014 dan Badan Pusat Statistik Provinsi DKI Jakarta, 2013). Sementara berdasarkan legalitas pemilikan lahan, permukiman kumuh dapat dibagi dua, yaitu permukiman kumuh di atas tanah legal dan ilegal (Imanda, 2013). Pada penelitian ini dipilih permukiman kumuh yang legal, karena jika ilegal rawan penggusuran yang dapat mengancam keberlanjutan permukiman kumuh tersebut.

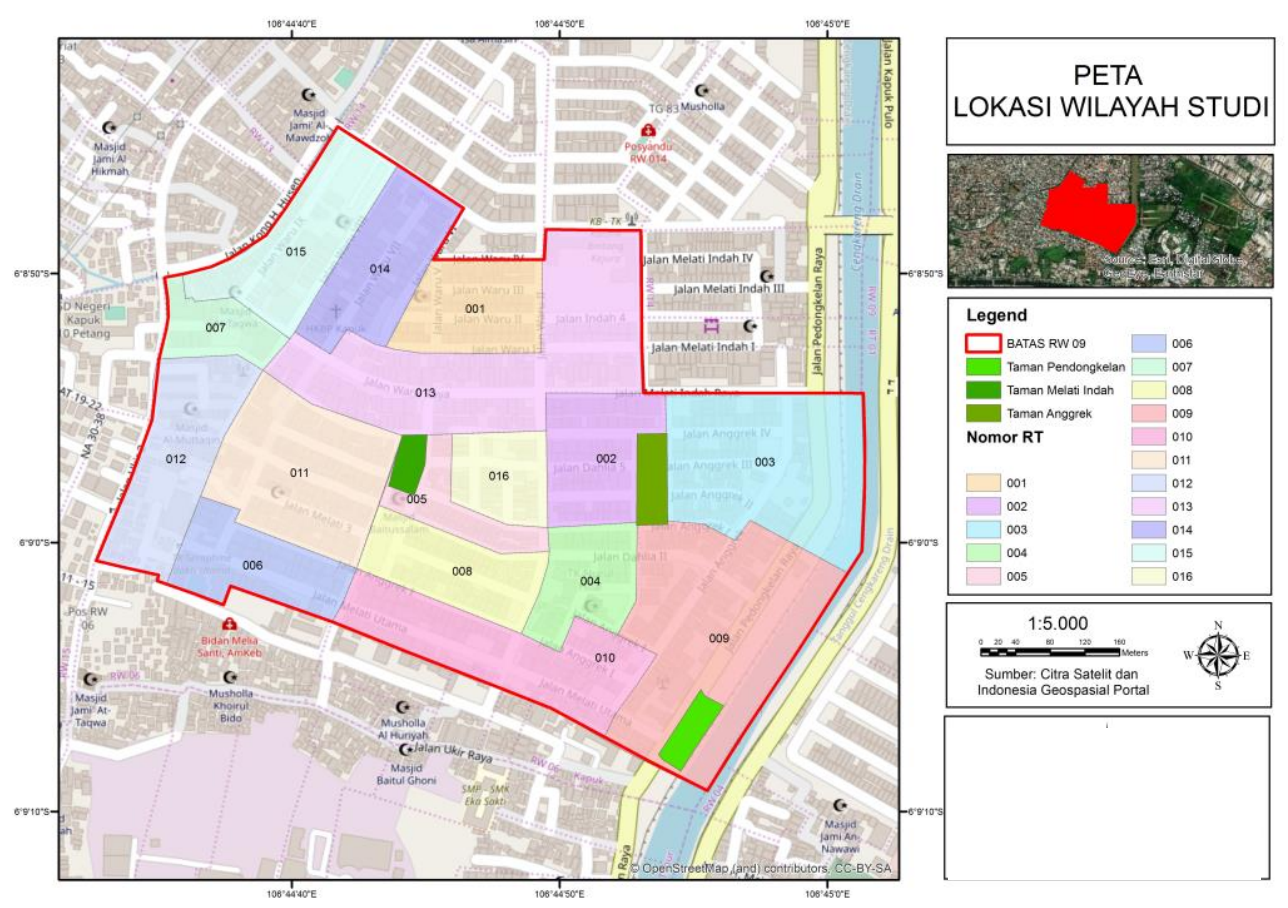

Gambar 1 Lokasi Penelitian

\section{Definisi dan Jenis Ruang Publik Multifungsi}

Ruang publik merupakan suatu tempat yang dapat diakses dan digunakan oleh umum (seluruh masyarakat) yang pada dasarnya merupakan suatu wadah untuk menampung aktivitas masyarakat, baik oleh individu maupun kelompok (Hakim, 1987 dalam Purnamasari, 2012). Berdasarkan sifatnya, ruang publik terbagi menjadi 2 jenis (Hakim, 2003 dalam Purnamasari, 2012), yaitu: ruang publik tertutup dan ruang publik terbuka. Ruang publik tertutup adalah ruang publik yang terdapat di dalam bangunan. Sementara ruang publik terbuka adalah ruang publik yang terdapat di luar bangunan.

Ruang publik terbuka merupakan area yang sering terjadi konflik pemanfaatan ruang (Anastasia, 2009). Ruang publik multifungsi adalah ruang publik yang mencakup berbagai macam orang, waktu, dan aktivitas (Whyte, 1980 dalam Nathiwutthikun, 2012). Berdasarkan hal tersebut, maka ruang publik multifungsi merupakan ruang yang dapat digunakan oleh seluruh kalangan masyarakat untuk berbagai aktivitas yang beragam pada waktu yang sama atau berbeda. Sebagai wadah yang digunakan oleh berbagai macam aktivitas maka ruang publik terbuka menjadi area yang memungkinkan terjadi konflik pemanfaatan ruang. Oleh karena itu, dalam penelitian ini dipilih ruang publik terbuka. 


\section{Pemanfaatan Ruang Publik Multifungsi di Permukiman Kumuh}

Jenis ruang publik di permukiman padat kota mencakup dua elemen utama, yaitu jalan dan taman (Mastutie, 2016). Pada hakikatnya, jalan diperuntukan untuk pergerakan, sehingga tidak dianjurkan untuk dimanfaatkan sebagai wadah beraktivitas. Dengan demikian, jenis ruang publik di permukiman kumuh yang diteliti adalah taman.

Pemanfaatan taman di permukiman kumuh secara garis besar meliputi aktivitas sosial, ekonomi, dan budaya. Untuk lebih jelasnya terkait pemahaman tiap-tiap jenis aktivitas di ruang publik diperlihatkan pada Tabel 1 .

Tabel 1. Aktivitas di Ruang Publik Multifungsi Permukiman Kumuh

\begin{tabular}{|c|c|c|}
\hline No & Jenis Kegiatan & Definisi \\
\hline 1 & Sosial & $\begin{array}{l}\text { Aktivitas sosial merupakan suatu kegiatan antar dua individu atau lebih yang } \\
\text { dilakukan bersama dan biasa terjadi di ruang publik. Aktivitas sosial berkaitan } \\
\text { dengan interaksi dan hubungan sosial orang-orang yang berada di dalamnya } \\
\text { (Napitupulu, } 2010 \text { dalam Sagitta, 2017; Clare Cooper Marcus dan Carolyn } \\
\text { Francis,1988). }\end{array}$ \\
\hline 2 & Ekonomi & $\begin{array}{l}\text { Aktivitas ekonomi merupakan suatu kegiatan yang berhubungan dengan } \\
\text { produksi, distribusi, serta penyediaan barang dan jasa yang bertujuan untuk } \\
\text { mendapat keuntungan (Gunawan, 2014). }\end{array}$ \\
\hline 3 & Budaya & $\begin{array}{l}\text { Aktivitas budaya merupakan aktivitas yang berhubungan dengan masalah } \\
\text { kebiasaan dan adat istiadat (Fasri Bachmid \& Ariyanto, 2017). }\end{array}$ \\
\hline
\end{tabular}

Sumber: Hasil kajian literatur, 2019

\section{Konsep Pemanfaatan Ruang Publik Multifungsi yang Berkelanjutan di Permukiman Kumuh}

Keberlanjutan pemanfaatan suatu taman dapat dicirikan oleh seberapa besar daya tarik dari taman tersebut. Daya tarik dapat dilihat dari jumlah aktivitas yang terjadi atau besarnya pengunjung yang datang ke tempat tertentu (Marpaung dalam Ariestaningrum, 2015). Mengacu pada prinsip-prinsip dasar ekologi, maka keberlanjutan akan terwujud jika terjadi interaksi, interdependensi, keragaman, dan harmoni. Seperti dikemukakan Yuono dan Harsiti (2015), ketika prinsip dasar ekologi sudah diaplikasikan pada suatu kawasan, maka kelestarian fungsi lingkungan akan berkelanjutan. Dengan demikian dalam mengukur keberlanjutan pemanfaatan taman digunakan interaksi, interdependensi, keragaman, dan harmoni. Tabel 2 memperlihatkan definisi aspek-aspek keberlanjutan.

Tabel 2. Definisi Aspek-aspek Keberlanjutan

\begin{tabular}{|c|c|c|}
\hline No & Aspek & Definisi \\
\hline 1 & Interaksi & $\begin{array}{l}\text { Interaksi merupakan hubungan antar perorangan, antar kelompok manusia, } \\
\text { maupun antara perorangan dengan kelompok dan saling mempengaruhi } \\
\text { (Gillin, } 1982 \text { dan Chaplin, } 2011 \text { dalam Istiqomah, 2015). }\end{array}$ \\
\hline 2 & Interdependensi & $\begin{array}{l}\text { Interdependensi merupakan hubungan saling bergantung, dapat dijumpai } \\
\text { pada hubungan kerjasama dan dapat saling menguntungkan. Dalam } \\
\text { penelitian ini adalah kebergantungan antar jenis aktivitas di ruang publik } \\
\text { (Ikbar, 2007). }\end{array}$ \\
\hline 3 & Keragaman & $\begin{array}{l}\text { Keragaman aktivitas ditandai dengan beragamnya jenis aktivitas sosial, } \\
\text { ekonomi, dan budaya di suatu ruang publik (Hernowo, Endy dan Navastara, } \\
\text { A.M, 2017). }\end{array}$ \\
\hline 4 & Harmoni & $\begin{array}{l}\text { Harmoni adalah suatu hubungan yang menimbulkan keselarasan, kecocokan, } \\
\text { dan keseimbangan serta tidak terjadi konflik antar sesama aktivitas } \\
\text { (Goesniadhie, } 2006 \text { dalam Komang, 2018). }\end{array}$ \\
\hline
\end{tabular}

Sumber: Hasil kajian literatur, 2019 
Berdasarkan definisi empat aspek keberlanjutan, selanjutnya dijabarkan indikator pemanfaatan ruang publik multifungsi yang berkelanjutan di permukiman kumuh, seperti diperlihatkan pada Tabel 3.

\section{METODE}

Penelitian ini menggunakan pendekatan kuantitatif dengan metode survey angket. Angket sebagai alat ukur menggunakan indikator seperti diperlihatkan pada Tabel 3.

Tabel 3. Indikator Keberlanjutan Pemanfaatan Ruang Publik

di Permukiman Kumuh

\begin{tabular}{|c|c|c|}
\hline Aspek & Keterangan & Indikator Keberlanjutan \\
\hline Interaksi & $\begin{array}{l}\text { Suatu taman dikatakan berhasil jika } \\
\text { dapat mewadahi aktivitas dan } \\
\text { interaksi antar aktivitas atau antar } \\
\text { anggota komunitas dengan baik. }\end{array}$ & $\begin{array}{l}\text { Intensitas aktivitas sosial di taman } \\
\text { Intensitas aktivitas ekonomi di taman } \\
\text { Intensitas aktivitas budaya di taman } \\
\text { Intensitas penggunaan taman untuk aktivitas }\end{array}$ \\
\hline Interdependensi & $\begin{array}{l}\text { Keberadaan taman menjadi aspek } \\
\text { penting terkait berlangsungnya } \\
\text { masing-masing jenis aktivitas dan } \\
\text { memberikan pengaruh positif. }\end{array}$ & $\begin{array}{l}\text { Tingkat pentingnya taman bagi } \\
\text { berlangsungnya masing-masing jenis aktivitas }\end{array}$ \\
\hline Keragaman & $\begin{array}{l}\text { Terdapat variasi jenis kegiatan yang } \\
\text { dapat dilakukan di taman, makin } \\
\text { banyak aktivitas maka fungsi taman } \\
\text { makin baik. }\end{array}$ & Variasi jenis aktivitas yang terjadi di taman. \\
\hline \multirow{3}{*}{ Harmoni } & $\begin{array}{l}\text { Tidak terjadi konflik perebutan ruang } \\
\text { antar jenis aktivitas yang } \\
\text { memanfaatkan taman. }\end{array}$ & $\begin{array}{l}\text { Kualitas manajemen penggunaan taman. } \\
\text { Intensitas konflik perebutan ruang yang } \\
\text { terjadi di taman. }\end{array}$ \\
\hline & $\begin{array}{l}\text { Taman menjadi tempat yang nyaman } \\
\text { untuk melaksanakan berbagai macam } \\
\text { jenis aktivitas, dinilai dari durasi } \\
\text { aktivitas. }\end{array}$ & $\begin{array}{l}\text { Durasi/lamanya penggunaan taman } \\
\text { Tingkat rasa nyaman saat memanfaatkan } \\
\text { taman sebagai tempat aktivitas. }\end{array}$ \\
\hline & $\begin{array}{l}\text { Taman digunakan untuk berbagai } \\
\text { macam jenis aktivitas tanpa ada yang } \\
\text { merasa terganggu satu sama lainnya }\end{array}$ & $\begin{array}{l}\text { Tingkat gangguan saat memanfaatkan taman } \\
\text { sebagai tempat aktivitas. }\end{array}$ \\
\hline
\end{tabular}

Sumber: Hariz, 2013; Metah, 2007; Misbah, 2018, Bambang Pranggono, 2017; Anita dan Gustya, 2012

Menilai pemanfaatan taman selain dengan menggunakan indikator keberlanjutan, agar taman mampu berfungsi baik sebagai wadah aktivitas maka perlu penyempurnaan dengan fasilitas-fasilitas pendukungnya. Standar minimum fasilitas untuk skala taman kota adalah bangku taman, tempat sampah, lampu taman (penerangan), jalur pedestrian, tempat parkir, plaza (arena serbaguna), toilet, gazebo, papan informasi, instalasi listrik dan jaringan drainase (Wibowo dan Mangasa, 2016). Sementara untuk lingkungan perumahan, jenis fasilitas taman disesuaikan dengan skala pelayanannya.

\section{Sampel Penelitian}

Unit analisis dalam penelitian ini adalah taman di permukiman kumuh. Sampel dalam penelitian ini adalah taman Pendongkelan, taman Melati Indah, dan taman Anggrek. Dalam mengukur tingkat keberlanjutan pemanfaatan taman digunakan metode survey angket dan observasi visual. Waktu penelitian dilakukan mulai tanggal 20 Juni sampai dengan 20 Juli 2019. Dalam survey angket, responden adalah pengguna taman yang dipilih sebagai sampel sejumlah 96 orang yang ditentukan dengan menggunakan Rumus Lemeshow sebagai berikut: 


$$
\mathrm{n}=\frac{\mathrm{Z}_{\alpha / 2}^{2} \mathrm{p}(1-\mathrm{p})}{\mathrm{d}^{2}}
$$

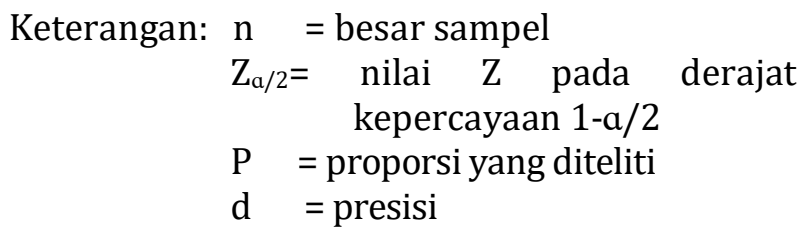

Pada penelitian ini tidak diketahui jumlah pengguna taman, sehingga diasumsikan $\mathrm{p}=0.5$, yakni sebanyak $50 \%$ adalah pengguna taman. Untuk presisi mutlak menggunakan $10 \%(\mathrm{~d}=0.10)$ dengan derajat kepercayaan $95 \%$ dan nilai Z pada derajat kepercayaan 1 $\alpha / 2$ dengan $\alpha=0.05$ adalah 1.96. Maka penghitungan jumlah responden pada penelitian ini adalah sebagai berikut:

$$
n=\frac{(1.96)^{2} \cdot(0.5)(1-0.5)}{(0.10)^{2}}=96 \text { resnonden }
$$

\section{Teknik Analisis Data}

Teknik untuk memvalidasi data digunakan uji statistik correlation bivariate dan reability analysis. Setelah dilakukan uji tersebut dilakukan distribusi frekuensi untuk menentukan klasifikasi kelas, dengan tahapan sebagai berikut (Sugiyono, 2012):

1. Menentukan jumlah kelas interval.

Jumlah kelas yang dipilih dalam penelitian ini ada tiga, yaitu kelas Tinggi (3), Sedang (2), dan Rendah (1).

2. Menentukan rentang data (range).

Untuk menentukan rentang data digunakan rumus:

Rentang Data $=$ Skor Maksimum - Skor Minimum

3. Menentukan panjang kelas interval.

Untuk menentukan panjang kelas interval digunakan rumus:

$$
\text { Panjang Kelas Interval }=\frac{\text { Rentang Data }}{\text { Jumlah Kelas Interval }}
$$

Dalam menilai tingkat keberlanjutan pemanfaatan taman sebagai ruang publik multifungsi di permukiman kumuh dilakukan analisis tentang tingkat interaksi, interdependensi, keragaman, dan harmoni yang merupakan aspek-aspek yang membentuk keberlanjutan. Dasar analisis adalah data numerik dari hasil koding atas jawaban angket yang menggunakan skala Likert.

\section{HASIL DAN PEMBAHASAN}

Sebelum menilai tingkat keberlanjutan taman, maka dikaji lebih dahulu tentang daya tarik taman; status tanah tempat taman berada; dan rencana peruntukannya. Ke tiga hal tersebut harus dipenuhi, karena jika tidak dipenuhi tidak akan dicapai keberlanjutan pemanfaatan taman.

Daya tarik taman dipengaruhi oleh aktivitas maupun fasilitas yang berhubungan sehingga dapat menarik minat pengunjung untuk datang (Marpaung dalam Ariestaningrum, 2015). Pada Tabel 4 diperlihatkan unsur-unsur daya tarik taman di masing-masing lokasi. Alasan mayoritas responden datang ke taman Pendongkelan dan taman Melati Indah karena kelengkapan fasilitas, sedangkan ke taman Anggrek karena luas taman. Daya tarik berdasarkan kelengkapan fasilitas taman diperlihatkan pada Tabel 5. Berdasarkan kelengkapan fasilitasnya, taman Melati Indah dan taman Pendongkelan 
memiliki kesamaan, sedangkan Taman Anggrek memiliki fasilitas yang lebih minim tetapi memiliki keunikan berupa pendopo yang tidak dimiliki taman yang lain.

Tabel 4. Tanggapan Responden Mengenai Daya Tarik Taman

\begin{tabular}{lccc}
\hline \multicolumn{1}{c}{ Daya Tarik } & Taman Pendongkelan & Taman Melati Indah & Taman Anggrek \\
\hline Luas taman & $6,2 \%$ & $21,9 \%$ & $40,6 \%$ \\
Keragaman aktivitas & $21,9 \%$ & $25 \%$ & $31,3 \%$ \\
Kelengkapan fasilitas & $37,5 \%$ & $40,6 \%$ & $12,5 \%$ \\
Akses mudah dijangkau & $34,4 \%$ & $12,5 \%$ & $15,6 \%$ \\
Total & $100 \%$ & $100 \%$ & $100 \%$ \\
\hline
\end{tabular}

Tabel 5. Kelengkapan Fasilitas di Setiap Taman

\begin{tabular}{cccc}
\hline Fasilitas & Taman Pendongkelan & Taman Melati Indah & Taman Anggrek \\
\hline Bangku taman & $\sqrt{ }$ & $\sqrt{ }$ & $\sqrt{ }$ \\
Tempat sampah & $\sqrt{ }$ & $\sqrt{ }$ & - \\
Fasilitas bermain anak & $\sqrt{ }$ & $\sqrt{ }$ & $\sqrt{ }$ \\
Lampu taman & $\sqrt{ }$ & $\sqrt{ }$ & - \\
Tempat parker & $\sqrt{ }$ & $\sqrt{ }$ & - \\
Balai & $\sqrt{ }$ & $\sqrt{ }$ & - \\
Toilet & $\sqrt{ }$ & - & $\sqrt{ }$ \\
Pendopo & - & $\sqrt{ }$ & - \\
Papan informasi & $\sqrt{ }$ & &
\end{tabular}

Sebelum menilai keberlanjutan suatu taman perlu diperhatikan kesesuaian lokasinya dengan zona peruntukannya. Ke tiga taman berlokasi pada lahan yang sudah sesuai peruntukannya, seperti diperlihatkan pada Gambar 2.

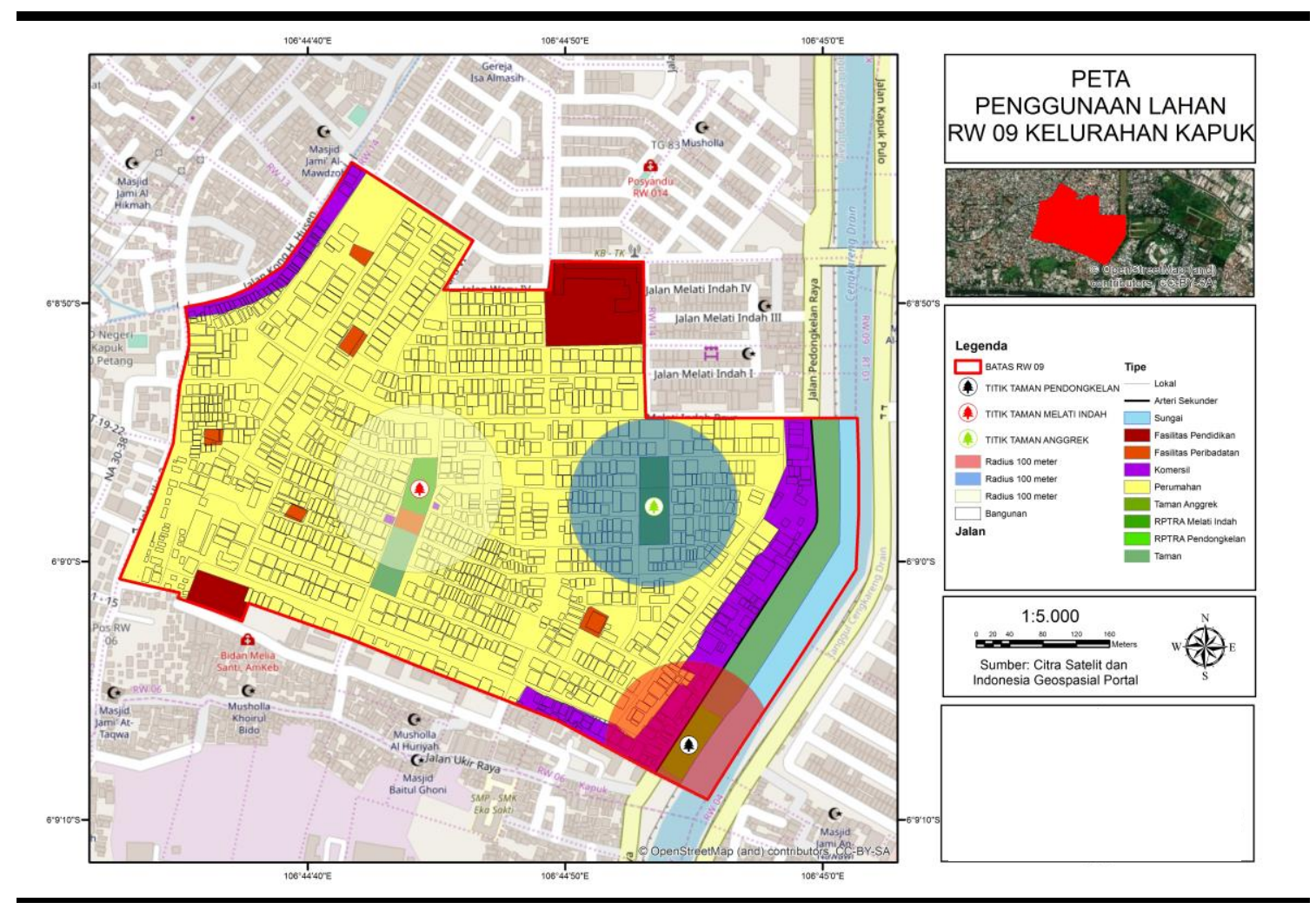

Gambar 2. Analisis Penggunaan Lahan 
Hasil analisis penggunaan lahan, menunjukkan bahwa lokasi ke tiga taman jika dibandingkan dengan Peraturan Daerah Nomor 1 Tahun 2014 tentang Rencana Detail Tata Ruang dan Peraturan Zonasi, penggunaannya sudah sesuai, yaitu zona taman kota/lingkungan (H2). Terkait dengan kesesuaian peruntukannya, maka ke tiga taman tersebut dapat terus dipertahankan.

\section{Analisis Tingkat Keberlanjutan Pemanfaatan Taman}

Pada Tabel 6 diperlihatkan hasil penilaian tingkat keberlanjutan pemanfaatan masing-masing taman, baik secara keseluruhan maupun berdasarkan aspek-aspek keberlanjutannya yang meliputi: interaksi, interdependensi, keragaman, dan harmoni.

Tabel 6. Penilaian Tingkat Keberlanjutan Pemanfaatan Taman

\begin{tabular}{|c|c|c|c|c|c|c|}
\hline \multirow{2}{*}{ Lokasi } & \multicolumn{4}{|c|}{ Aspek Keberlanjutan } & \multirow[b]{2}{*}{ Total } & \multirow{2}{*}{$\begin{array}{c}\text { Tingkat } \\
\text { Keberlanjutan }\end{array}$} \\
\hline & Interaksi & Interdependensi & Keragaman & Harmoni & & \\
\hline $\begin{array}{c}\text { Taman } \\
\text { Pendongkela } \\
n\end{array}$ & $\begin{array}{c}2 \\
(66,7 \%)\end{array}$ & $2(66,7 \%)$ & $2(66,7 \%)$ & $\begin{array}{c}3 \\
(100 \%)\end{array}$ & $\begin{array}{c}9 \\
(75 \%)\end{array}$ & Tinggi \\
\hline $\begin{array}{c}\text { Taman } \\
\text { Melati Indah }\end{array}$ & $\begin{array}{c}2 \\
(66,7 \%)\end{array}$ & $2(66,7 \%)$ & $2(66,7 \%)$ & $\begin{array}{c}2 \\
(66,7 \%)\end{array}$ & $\begin{array}{c}8 \\
(66,7 \%)\end{array}$ & Sedang \\
\hline $\begin{array}{c}\text { Taman } \\
\text { Anggrek }\end{array}$ & $\begin{array}{c}2 \\
(66,7 \%)\end{array}$ & $2(66,7 \%)$ & $1(33,3 \%)$ & $\begin{array}{c}2 \\
(66,7 \%)\end{array}$ & $\begin{array}{c}7 \\
(58,3 \%)\end{array}$ & Rendah \\
\hline
\end{tabular}

Keterangan: $1=$ rendah; $2=$ sedang; $3=$ tinggi

Berdasarkan penilaian tingkat keberlanjutan pemanfaatan taman, dapat diketahui bahwa tingkat keberlanjutan taman Pendongkelan memiliki nilai tinggi, selanjutnya taman Melati Indah dengan nilai sedang dan taman Anggrek dengan nilai rendah. Berdasarkan Tabel 6, aspek yang membedakan tingkat keberlanjutan pemanfaatan antar taman adalah aspek keragaman aktivitas dan aspek harmoni. Artinya, dengan keragaman aktivitas yang tinggi tetapi disertai adanya harmoni dapat menciptakan daya tarik yang tinggi dan menjamin keberlanjutannya. Dalam kondisi seperti demikian (keragaman tinggi tetapi dalam harmoni) berkaitan dengan pengelolaan taman.

Intensitas dan keragaman aktivitas yang tinggi di satu sisi dan di sisi lain luas taman yang terbatas dapat menimbulkan konflik pemanfaatan ruang di taman. Konflik pemanfaatan ruang antara aktivitas sosial dan aktivitas ekonomi di taman dapat menggusur salah satunya. Kebutuhan ruang usaha (ekonomi) secara tidak langsung dapat menggeser fungsi sosial dari ruang publik menjadi ruang untuk kegiatan ekonomi, dan mengesampingkan nilai sosial maupun kondisi kualitas fisik ruang publik tersebut (Purwanto, Edi. 2014). Berkaitan dengan reduksi konflik pemanfaatan ruang, dibutuhkan kehadiran pengelola taman untuk memelihara keberlanjutan fungsi taman (Pranggono, 2017). Dengan adanya pengelola taman maka jadwal pemanfaatan taman antar aktivitas dapat diatur dan dipantau.

Pada Gambar 3 diperlihatkan peta hasil penilaian tingkat keberlanjutan pemanfaatan taman. Berdasarkan hasil penilaian tingkat keberlanjutan pemanfaatan masing-masing taman, dapat diketahui bahwa terdapat beberapa aspek yang turut mempengaruhi tingkat keberlanjutan tersebut. Berikut uraiannya.

\section{Taman Pendongkelan}

Berdasarkan hasil analisis, tingkat keberlanjutan pemanfaatan ruang di taman Pendongkelan menunjukkan tingkat keberlanjutan pemanfaatan tinggi. Dengan luas yang terbatas $\left(237 \mathrm{~m}^{2}\right)$, taman Pendongkelan cukup menampung berbagai macam aktivitas masyarakat. Intensitas konflik pemanfaatan ruang antar aktivitas di taman ini cenderung rendah karena masing-masing aktivitas sudah terjadwal dengan baik oleh pengelola. Total aktivitas yang rutin memanfaatkan taman Pendongkelan berjumlah 9 aktivitas. Fasilitas 
yang tersedia di taman Pendongkelan cukup lengkap, meliputi bangku taman, tempat sampah, fasilitas bermain anak, lampu taman, tempat parkir, balai, toilet, dan papan informasi. Kondisi taman Pendongkelan cukup menarik dengan desain warna-warni yang indah. Untuk mengakses taman Pendongkelan cukup mudah karena berada di pinggir jalan arteri sekunder. Tampak bahwa pengunjung ada yang berasal dari luar wilayah RW 09 Kapuk karena tertarik dengan kelengkapan fasilitas dan desain taman Pendongkelan.

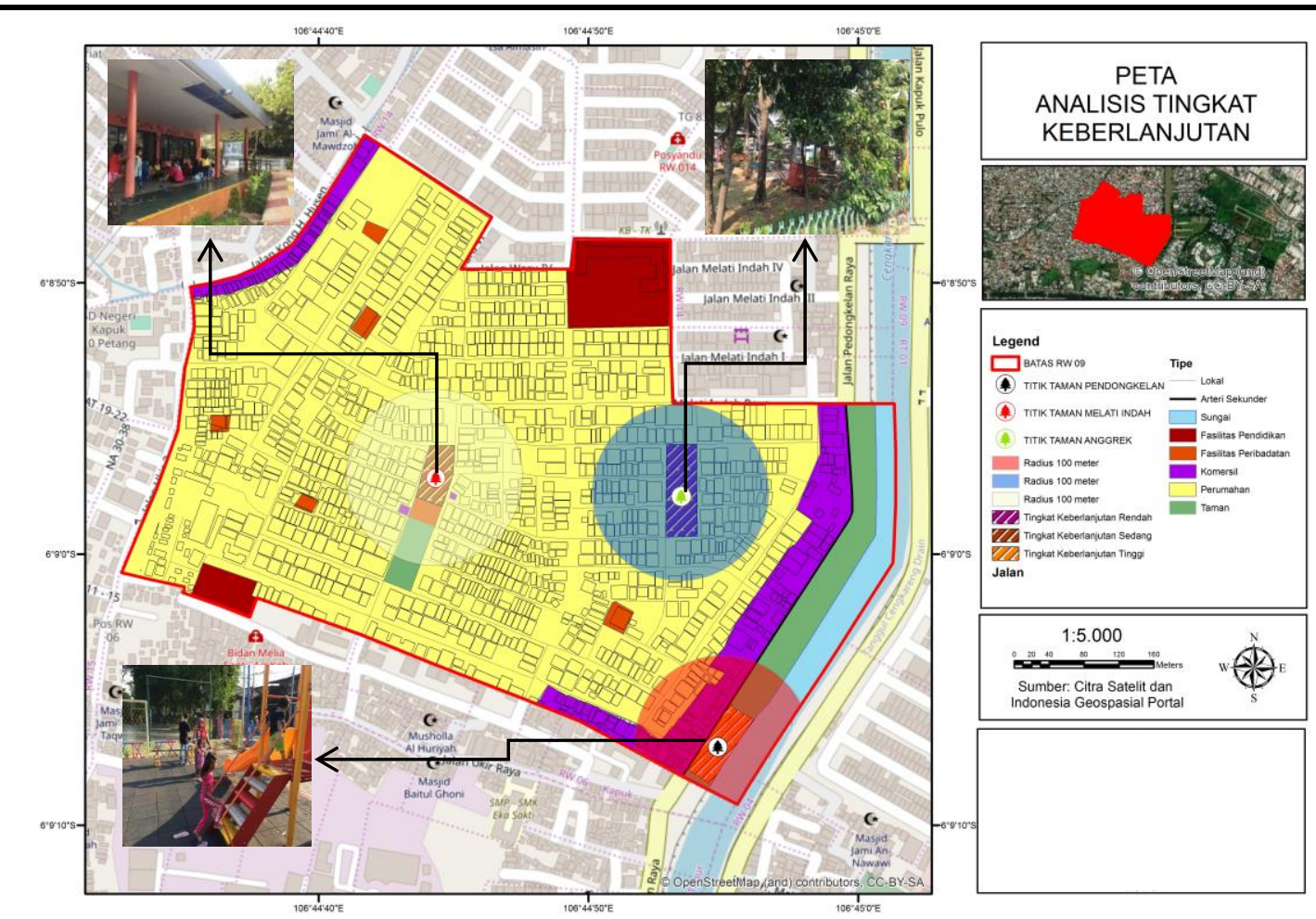

Gambar 3. Peta Analisis Tingkat Keberlanjutan Taman

Untuk menjaga keberlanjutan pemanfaatan taman Pendongkelan, hal yang perlu dilakukan adalah pengecekan rutin atas kondisi taman (kebersihan dan kualitas fasilitas) dan kesiapan untuk melakukan pelebaran taman ke depan seiring dengan makin banyaknya pengguna taman.

\section{Taman Melati Indah}

Berdasarkan hasil penilaian tingkat keberlanjutan pemanfaatan taman Melati Indah diperoleh nilai sedang. Luas taman terbatas sehingga menimbulkan rasa kurang nyaman bagi pengguna. Di taman ini terjadi tumpang tindih aktivitas yang mempengaruhi tingkat harmoni. Selain luas taman terbatas, pengaturan jadwal kegiatan juga kurang teratur. Jenis fasilitas yang terdapat di taman Melati Indah secara keseluruhan mirip dengan fasilitas yang terdapat di taman Pendongkelan tetapi dari segi kualitas, fasilitas di taman ini kurang terawat walaupun untuk saat ini masih berfungsi baik. Kelengkapan fasilitas menjadi daya tarik untuk menggunakan taman ini.

Tingkat keragaman aktivitas di taman Melati Indah meliputi 6 aktivitas. Taman ini mampu menampung berbagai macam aktivitas masyarakat dengan cukup baik. Akses untuk mencapai taman ini hanya dapat menggunakan kendaraan pribadi. 
Sebagai taman yang memiliki tingkat keberlanjutan sedang, maka agar jumlah pengguna taman terus meningkat perlu diperhatikan kualitas fasilitas (perlu pengecatan ulang agar taman lebih menarik) dan aksesibilitasnya (penyediaan papan petunjuk jalan menuju taman).

\section{Taman Anggrek}

Tingkat keberlanjutan pemanfaatan Taman Anggrek adalah rendah. Tingkat keragaman aktivitas di taman ini berjumlah 5 jenis aktivitas. Luas taman ini adalah 2.196 meter persegi dan merupakan yang terluas bila dibandingkan dengan dua taman lainnya. Luasnya taman ini merupakan daya tarik bagi pengguna. Adanya tempat pembuangan sampah di taman ini mengganggu estetika taman dan menghasilkan bau yang kurang sedap. Aktivitas yang dijumpai umumnya adalah aktivitas sosial biasa seperti mengobrol dan bermain.

Jenis fasilitas taman ini sangat minim, hanya tersedia lapangan olahraga, fasilitas bermain anak (perosotan dan besi panjat), serta pendopo. Minimnya fasilitas menjadi salah satu alasan masyarakat kurang tertarik untuk melaksanakan aktivitas di taman tersebut. Aksesibilitas menuju Taman Anggrek cukup terganggu dengan adanya parkir liar di beberapa badan jalan. Berbeda dengan dua taman lainnya, taman Anggrek tidak memiliki lahan parkir khusus untuk pengunjung. Hal tersebut menyebabkan pengunjung merasa kurang nyaman karena jalan yang semestinya digunakan untuk mobilitas kendaraan terganggu fungsinya.

Upaya untuk meningkatkan tingkat keberlanjutan pemanfaatan Taman Anggrek adalah melengkapi fasilitas dari segi kuantitas maupun kualitas (design yang menarik), penyediaan lahan parkir untuk pengunjung, serta menindak tegas pemanfaatan taman yang tidak semestinya (komersialisasi ruang taman dan taman yang digunakan untuk TPS). Tingkat keberlanjutan pemanfaatan taman sebagai ruang publik multifungsi di permukiman kumuh perkotaan merupakan hal penting karena merupakan wahana interaksi antar komunitas untuk berbagai tujuan, baik individu maupun kelompok (Purwanto, Edi. 2014). Dalam hal ini, pemanfaatan ruang publik dapat membangun suatu hubungan sosial dan menjadi nilai tambah bagi suatu lingkungan di permukiman kumuh perkotaan.

Berdasarkan uraian terkait tingkat keberlanjutan masing-masing taman, selain aspek kualitas dan kuantitas kondisi fisik taman seperti tersedianya bangku taman, tempat sampah, lampu taman (penerangan), jalur pedestrian, tempat parkir, plaza (arena serbaguna), toilet, gazebo, papan informasi, instalasi listrik dan jaringan drainase sebagai standar minimun fasilitas untuk taman skala kota (Wibowo dan Mangasa, 2016) perlu diperhatikan pula keberadaan pihak pengelola. Untuk menjaga dan memperbesar tingkat keberlanjutan taman, dalam pengelolaan perlu dilakukan hal-hal berikut: perawatan kondisi fasilitas, penyempurnaan fasilitas taman sesuai standar, penyediaan lahan untuk perluasan taman ke masa depan, perbaikan akses, peningkatan desain dan vegetasi taman, serta penyediaan peraturan tentang pengelolaan dan tata letak taman.

Selain pengelolaan taman, perhatian pada aspek ekonomi, sosial, dan budaya pengguna perlu mendapat tempat. Hal ini mengingat taman merupakan fasilitas publik yang didorong agar mampu menampung segala aktivitas sosial, ekonomi, dan budaya secara maksimal bagi masyarakat kota di permukiman kumuh sehingga berpengaruh pada kualitas kehidupan mereka. Agar menjadi berkelanjutan, maka pemanfaatan taman kota sebagai ruang publik yang menunjang kelangsungan aktivitas sosial, ekonomi, budaya masyarakat permukiman kumuh dapat terus menerus berjalan.

Hasil penelitian ini dapat dijadikan sebagai referensi untuk penelitian lebih lanjut. Beberapa penelitian yang dapat dilakukan adalah tentang fungsi taman dalam peningkatan kualitas hidup penghuni permukiman kumuh; pengaruh kualitas ruang 
publik pada tingkat kekumuhan permukiman; dan penilaian kualitas ruang terbuka publik berdasarkan good public space index.

\section{KESIMPULAN}

Terdapat perbedaan tingkat keberlanjutan pemanfaatan ruang publik multifungsi di tiga taman yang diteliti. Tingkat keberlanjutan tinggi terjadi di taman Pendongkelan; tingkat sedang di taman Melati Indah; dan tingkat rendah di taman Anggrek. Aspek keberlanjutan yang menjadi pembeda adalah aspek keragaman dan harmoni antar aktivitas. Untuk memelihara dan meningkatkan keberlanjutan pemanfaatan taman diperlukan pengelolaan taman untuk meningkatkan keragaman (sebagai daya tarik taman) di satu sisi dan di sisi lain menjaga harmoni antar aktivitas agar tidak saling mengganggu bahkan menggeser aktivitas lain. Dalam pengelolaan taman perlu diperhatikan ketersediaan jenis fasilitas taman, luas taman, dan aksesibilitasnya.

\section{DAFTAR PUSTAKA}

Ariestaningrum, I.D. (2015). Peran Dinas Kebudayaan Pariwisata dan Kominfo dalam Pengembangan Objek Wisata Air Terjun Tanah Merah di Kelurahan Tanah Merah Kecamatan Samarinda. 3(1), 253-264.

Bachmid, F \& Ariyanto. (2017). Strategi Penanganan Kawasan Permukiman Kumuh Kota. 166-176.

Banteng, B. S. D. (2015). Menuju Kota Layak Huni dan Berkelanjutan Studi Kasus Kota Gorontalo. (November), $1-7$.

Budiawan, H. (2014). Rusunawa di Mojosongo Surakarta dengan Pendekatan Arsitektur Modern Tropis. Artikel publikasi.

Gunawan, W.Y. (2014). Kontribusi Usaha Perkebunan Nenas Pemerintah Kabupaten Siak dalam Meningkatkan Pendapatan Ekonomi Masyarakat Menurut Prespektif Ekonomi Islam (Studi Kasus Desa Teluk Batil Kecamatan Sungai Apit).

Hernowo, E., \& Navastara, A. M. (2017). Karakteristik Ruang Publik Terpadu Ramah Anak (RPTRA) Bahari di Kecamatan Cilandak. (September). https://doi.org/10.12962/j23373539.v6i2.25293

Ikbar, Y. (2007). Ekonomi Politik Internasional 2: Implementasi Konsep dan Teori. Bandung: PT Refika Aditama. http://lib.lemhannas.go.id/public/media/catalog/0010011600000000244/swf/5560/mobile/index.html\#p=5

Imanda, A. (2013). Gerakan Tanah Studi Kasus: Permukiman Sekitar Ngarai Sianok di Kelurahan Belakang Balok, Kota Bukittinggi. 24(2), 141-156.

Istiqomah, S.N. (2015). Pengaruh Kematangan Emosi dan Kecerdasan Sosial terhadap Interaksi Sosial Siswa Program Akselerasi.

Loukaitou-Sideris, A., \& Ehrenfeucht, R. (2009). Sidewalks Conflict and Negotiation over Public Space.

Mastutie, F., Supardjo, S., \& Prijadi, R. (2016). Ruang Publik pada Permukiman Padat Kota di Kawasan Pesisir. (1), 197-202.

Nathiwutthikun, K., Peerapun, W., \& Paksukcharern, K. (2012). The Logic of Multi-Use of Public Open Spaces in Chiang Mai City. 45-68.

Novianty, R., Rahmayanti, H., \& Neolaka, A. (2012). Evaluasi Mengenai Kuantitas dan Kualitas Ruang Terbuka Hijau di Wilayah DKI Jakarta. VII(1), 100-125.

Peraturan Daerah Nomor 1 Tahun 2014 Rencana Detail Tata Ruang dan Peraturan Zonasi. (2014). 1-444.

Purnamasari, S.A. (2012). Kajian Spasial Ruang Publik (Public Space) Perkotaan Untuk Aktivitas Demonstrasi Mahasiswa di Kota Makassar. 27-36.

Purwanto, E. (2014). Privatisasi Ruang Publik dari Civic Centre Menjadi Central Business District (Belajar dari Kasus Kawasan Simpang Lima Semarang). 153-167.

Sagitta, A.A. (2017). Hubungan Aktivitas Sosial dengan Kualitas Hidup Lansia di Padukuhan Karang Tengah Nogotirto Gamping Sleman Yogyakarta.

Sumaatmaja, D. M., \& Pranggono, B. (2016). Kajian Berkelanjutan Taman Tematik Berdasarkan Persperktif Pengunjung (Studi Kasus: Kecamatan Bandung Wetan, Kota Bandung ). 369-377.

Sutresno, A \& Setioko, B. (2017). Pengaruh Keberadaan Alun-Alun sebagai Ruang Publik terhadap Karakter Kawasan Pusat Kota di Kisaran. 13(024), 1-13.

Swasta, K. (2018). Faktor-Faktor yang Mempengaruhi Harmonisasi Perdamaian Antaretnis. 
Undang-Undang Nomor 1 Tahun 2011 Perumahan dan Permukiman, (2011).

Wibowo, A., \& Ritonga, M. (2016). Kebutuhan Pengembangan Standar Nasional Indonesia Fasilitas Taman Kota. 161-170.

Widodo, N. (2013). Evaluasi RW Kumuh DKI Jakarta. Penerbit: Badan Pusat Statistik Provinsi DKI Jakarta.

Yuono, D \& Harsiti. (2015). Perencanaan Lanskap Kawasan Pesisir dengan Konservasi dan Wisata di Hutan Mangrove. 338-346. 